\title{
SATYRA POLITYCZNA NA ŚLĄSKU CIESZYŃSKIM W OKRESIE MIĘDZYWOJENNYM
}

\section{MICHA PRZYWARA}

ABSTRACT The purpose of this article is to paint the picture of the issue of political satire in "Cieszyn" Silesia. It is supposed that the most intensive time of political satire in "Cieszyn" Silesia was a interwar time, when constituted Czechoslovakia and Poland. This topic it's new in regional study and the present article deals with the development political satire in this time and emphasizes interestingly local elements.

KEY WORDS Gwiazdka Cieszyńka - “Jura i Jónek”, Pokrzywy, Szerszeń, political satire, Teschen Silesia

CONTACT Ostravská univerzita; michal.przywara@osu.cz 
Niniejszy artykuł jest częścią szerszych badań nad komizmem Śląska Cieszyńskiego. W dyskursie teoretycznym dotyczącym komizmu istnieje szereg polisemicznych pojęć oraz nadmierna ilość interpretacji poszczególnych terminów. W swej pracy badawczej nad specyfiką komizmu w literaturze Śląska Cieszyńskiego wychodzę z ogólnego założenia, że komizm jest określeniem szerokim i definiuje zjawiska wywołujące efekt śmieszności. Częścią komizmu jest humor, satyra, ironia i groteska, z czego satyra najmocniej z wszystkich form komizmu jest skierowana przeciw czemuś a równocześnie za czymś (może być użyta w dobrych lub złych celach w zależności od poglądów). Satyrze szczególnie służy polityka, bowiem satyra, zdaniem Tomasza Stępnia, od początku swego istnienia przejawiała związki z rzeczywistością pozaartystyczną, znalazła się na marginesie sztuki, w niższych rejonach literatury, w sferze edukacji społecznej, kultury popularnej, polityki i rozrywki, stała się wytworem o charakterze konsumpcyjnym i rozrywkowym dla mało wymagającej publiczności (Stępień 1996: 48-49, 295). Satyra polityczna od wieków tworzy istotny element w rywalizacji o władzę. Jak potwierdzają liczne prace literaturoznawcze, historyczne, socjologiczne komizm od zawsze był obecny w komunikacji politycznej jako ludyczny element dyskursu. Komizm najpełniej rozwija się w epoce kryzysów, a satyra nasila się w okresach społecznych przesileń, nie inaczej było temu na terenach Śląska Cieszyńskiego.

Zanim przejdziemy do tematu należy przypomniej, iż zdecydowana większość autorów np. Kazimierz Wyka, Julian Krzyżanowski, Jan Trzynadlowski czy Jerzy Ziomek oddziela, w uogólnieniu, komizm czysty (prosty lub humorystyczny) od komizmu satyrycznego. Jerzy Ziomek uważał komizm satyryczny za agresywny, towarzyszący degradacji, ośmieszający i kompromitujący. Natomiast komizm humorystyczny określa pobłażliwość i życzliwość, który może wskazywać niedoskonałości, ale te mogą być wartością i źródłem zadowolenia (Ziomek 1966: 330). Teoretyk sztuki i filozof Bohdan Dziemidok powyższy podział bardziej specyfikuje wyodrębniając komizm prosty (uczuciowo jednorodny, z brakiem elementów wartościująco-refleksyjnych) - można do niego zaszeregować wszelkie dowcipy i anegdoty okolicznościowe, bez kontekstu politycznego i zaangażowania społecznego, i komizm złożony, który dzieli jeszcze na humorystyczny i niehumorystyczny, przy czym w komizmie humorystycznym pochwała równoważy lub przeważa negację, a niehumorystyczny ma charakter dezaprobujący. W obrębie ostatniego wyróżnia zaangażowany społecznie komizm satyryczny, który aktywnie przeciwstawia się złu w imię konkretnych ideałów oraz komizm niesatyryczny - pozbawiony społecznego zaangażowania, zjadliwy i agresywny, u którego negacja nie ma na celu działań reformatorskich i służy wyłącznie do zmuszenia odbiorcy do samodzielnej refleksji, bądź do zademonstrowania oryginalności twórcy (Dziemidok 1967: 79-81). Przy analizie poszczególnych czasopism satyryczno-humorystycznych pojawiających się Śląsku Cieszyńskim do II wojny światowej zauważono wszystkie powyżej sklasyfikowane rodzaje komizmu, jednak przedmiotem niniejszego artykułu jest zbadanie komizmu satyrycznego, z wyszczególnieniem satyry politycznej.

Do pierwszych utworów satyrycznych w języku polskim należy rubryka „Jura i Jónek” pojawiająca się regularnie w „Gwiazdce Cieszyńskiej” od 1856 roku w formie ludowych dialogów w gwarze cieszyńskiej. Tematyka rozmów była różnorodna, komentowano społeczne zmiany i zjawiska (np. epidemię tyfusu i cholery, wycinkę drzew w Beskidach, brak ludzkiego szacunku, pogoń za pieniądzem), wypowiadano się na tematy związane z polityką monarchii, później Polski. Nie stroniono od komentarzy polityki regionalnej, np. sprawa niemieckiej szkoły 
w Mazańcowicach, często rozmawiano o władzy odrodzonej Rzeczypospolitej, dużą sympatią darzono m.in. Ignacego Paderewskiego:

„Jónek: Myślę, że teraz bee lepi, ten nowy minister, pisze sie Ignac Paderewski, umie snoci straszecznie szumnie na klajwierzu wygrować, to je mądro głowa i dobry kamrat tego najwyższego amerykana Wilsona i mo wszędy bardzo dobre kondowita".

(Gwiazdka Cieszyńska nr 7, 1919:1)

Konflikt o Śląsk Cieszyński również stał się tematem licznych rozmów, ze względu na polski charakter gazety z dialogów oczywiście wynikała obrona polskich dążeń na tym terenie:

„...Czeszy se na nas ostrzą zęby i wszystkich Polaków na Śląsku by nejraczy zjedli jak hanacki knedle z powidłami sakompikom naroz, ale by im to djabligo na dołku leżało, bo nas je sztwierć miliona i nie daliby se z nami rady".

(Gwiazdka Cieszyńska nr 1, 1919: 2)

Żartobliwy ton dialogów, piękna gwara i ludowa mądrość głosząca najczęściej pochwałę chłopskiego rozumu ludu śląskiego dostarczały gazecie rzesze czytelników. Rozmowy „Jury i Jónka" stworzył Edward Świerkiewicz, poeta, malarz, publicysta i działacz społeczny pochodzący z Myślenic, autor pierwszego na Śląsku Cieszyńskim utworu dramatycznego pisanego gwara pt. „Polok w Ślasku, lebo dwa wachtorze w jednej dziedzinie. Obrozek sielski w trzech oddziołkach przez E. Świerka” (1856). Po jego śmierci dialogi były kontynuowane aż do zaniku „Gwiazdki” i stały się wzorem dla innych podobnych rubryk w śląskiej prasie. Rozmowy nie reprezentują satyry politycznej w czystej postaci, bowiem nie chodzi w nich o atakowanie przeciwnika politycznego. Sympatii politycznych autorzy dialogów nie skrywali i nie tworzyli bezstronniczych komentarzy (czasami umacniali istniejący stereotyp - np. Żyda), jednak w tonie wypowiedzi i w użyciu słownictwa daleko im do innych zjadliwych satyr i karykatur tego okresu. „Jura i Jónek” są swoistą kontynuacją sowizdrzalskiego bohatera, ludowego sprytnego chłopa, potrafiącego na swój sposób określać obserwowany świat.

Wzmożony rozwój satyry politycznej na Śląsku Cieszyńskim możemy zauważyć na początku XX wieku, w okresie nasilających się dążeń narodowych Polaków i Czechów. Pierwszym czasopismem satyryczno-humorystycznym były „Pokrzywy” (potwierdza to podtytuł pisma: „Ucieszne pismo ludowe dla rozweselenia i rozrywki”), wydawane w Cieszynie w latach 1909-1920 pod redakcją Jerzego Bielesza. Ośmiostronicowy dwutygodnik był pisany w języku polskim i w gwarze cieszyńskiej. Treść czasopisma składa się głównie z dowcipów, anegdot, karykatur, mikro-opowiadań oraz wierszy. Rzadziej występuje w nim komizm prosty, jak np. wiersz „My rządzimy światem! A nami kobiety!” (Pokrzywy nr 6, 1918: 6) lub dowcip:

\section{Studyum z konieczności}

Kucharka: Ty uczysz się po francusku?

Pokojówka: A co mam robić? Odkąd państwo

zauważyło, że podstuchuje pod drzwiami, rozmawiaja zawsze po francusku ze sobą.

(Pokrzywy nr 3, 1910:3) 
W większości utwory niosą elementy komizmu satyrycznego, a jego adresatami są najczęściej politycy austriaccy i ich sposób rządzenia, np. karykatura przedstawiająca Leona Bilińskiego, który w latach 1909-1910 piastował stanowisko ministra skarbu Austrii (Pokrzywy nr 1, 1909: 4) lub karykatura pt. „Sprawy bankowe Austro-Węgier”, dopełniona komentarzem:

„Tu felix Austria nube! (ti. Szczéśliwa Austryo jesteś tem matżeństwem). Wołano wtenczas, kiedy rozchodziło się o zjednoczenie Wegier z Austrya. Dzisiaj jednak Austrya mółgłaby być zadowolona, gdyby od Wegier odtaczona byta. Cóż to za małżeństwo, skoro pan matżonek ze spólnej miski wszystko zjada a dla biednej Austryi nic nie pozostawi".

(Pokrzywy nr 1, 1909: 1).

W satyrze politycznej często ma miejscie dyskredytacja komiczna o charakterze personalnym, tak też dzieje się w „Pokrzywach” jednak raczej w sposób umiarkowany, np. poprzez zdrobnienie imienia, przekręcenie nazwiska, np. Wiluś Kajzer (Wilhelm II), stary Francek (Franciszek Józef I), Edek lub angielski Eduś (Edward VII) czy skierowanie się do władców w sposób koleżeński, używając często gwary jako narzędzia akcentującego familiarność: „Wiluśku ten swój naród miołeś na szpagatach i drutach uwiązany i skokali ci błoźni tak jako im poręczyłeś" (Pokrzywy nr 18, 1918: 8). Spora część utworów jest skierowana przeciwko Czechom, czeskim politykom i tzw. Ślązakowcom ${ }^{1}$, np. karykatura czeskiego lwa trzymającego posłów Karla Kramařa i Václava Klofáča, antyczeska przeróbka „Roty” Marii Konopnickiej, wiersz „Gruszowska ballada” i wiele innych (Pokrzywy nr 1, 1909: 2-6). Wiersze umieszczone na łamach „Pokrzyw” są raczej niskich lotów, niektóre wręcz na granicy wierszoklectwa, prezentują prymitywną poezję agitacyjno-polityczną. Jak na pismo satyryczne przystało większość autorów drukowała pod pseudonimami. Do aktywniejszych należał Andrzej Chmurny, właściwie Józef Gabriel Mondchein (1883-1961), polski poeta i pisarz urodzony w Siedlcach, w twórczości zbliżony do nurtu polskiej poezji proletariackiej. Jego twórczość literacka przeszła bez większego echa, najwięcej rozgłosu przyniósł mu tomik wierszy „Ciernie śląskie” (1920, Lwów), gdzie wyraził radykalny protest przeciwko uciskowi społecznemu i narodowościowemu na Śląsku Cieszyńskim. Na jego styl poetycki spory wpływ wywarła twórczość czeskiego poety Petra Bezruča.

W okresie sporu o tereny Śląska Cieszyńskiego (1919-20) między nowo powstałą Rzeczpospolitą a Czechosłowacją karykatura i satyra polityczna coraz bardziej radykalizuje się, zwłaszcza przed planowanym plebiscytem, kiedy służyć miała do pozyskiwania głosów. Polski historyk Józef Chlebowczyk opisał atmosferę kampanii następująco:

„Nie byto środka, którym by się nie postużono w tej zaciętej i nieubłaganej walce: od odwotywania się do dziedzictwa przodków, do przywiazania do mowy ojczystej, uczuć patriotycznych słowem od apelowania do stanów emocjonalnych poprzez agitację eksponującą argumenty ekonomiczne... do różnorodnych form psychicznego nacisku i terroru fizycznego wtącznie".

(Chlebowczyk, 1971: 145-146).

1 Ślązakowcami nazywano członków lub sympatyków partii Śląska Partia Ludowa, założonej przez Józefa Kożdonia i działającej w Austro-Węgrzech od 1909 r, a potem w Czechosłowacji w latach 1921-38. Partia zaliczana jest do śląskich ruchów separatystycznych, akcentujących odrębność narodową Ślązaków od Polaków. 
Każda ze stron miała własną komisję plebiscytową, która prowadziła aktywną agitację polityczną. Czeska strona w tym celu założyła czasopismo satyryczne „Kocur”, później przemianowane na „Nasz Kocur”, którego redaktorem był czeski nauczyciel z Ostrawy Alois Adamus, piszący pod pseudonimem Jan Gwizda. Czasopismo koncentrowało się na wyszydzaniu słabości gospodarczej Rzeczypospolitej, na krytyce kościoła katolickiego i siły stanu duchownego, który utrzymywać będzie nierówność społeczną. Również karykatury w czasopiśmie „Ślązak”, wydawanym przez Ślązakowców, podkreślały nierówność społeczną i biedę państwa polskiego, dodając jeszcze antysemickiego kolorytu. Jedną z najbardziej znanych karykatur jest obraz rozmawiającej śląskiej pary (chłopak i dziewczyna) z tzw. galicyjską trójcą - ksiądz, Żyd i polski oficer. Ślązakowcy apelowali do niezdecydowanych narodowo obywateli o czujność, bowiem wraz z przyłączeniem Śląska Cieszyńskiego do Polski zagraża regionowi migracja robotników z Galicji oraz napływ galicyjskich urzędników. Polska kampania plebiscytowa akcentowała antyklerykalizm czeski oraz kwestię słowacką i niestabilność wewnętrzną Czechosłowacji, która przedstawiana była jako zlepek narodowości (Niemcy, Czesi, Węgrzy, Słowacy), w którym prawdziwi Czesi tworzą mniejszość (Novotný, 2012: 217-224). W tym celu wyszły 2 broszury pamfletowo-agitacyjne napisane w formie dialogu: „Rozmowa Ślązaka z Czechem: jak Jerzy Węglorz rozmawiał z Czechem Naprstkiem” (Cieszyn 1919) i „Rozmowa Ślązaka z Czechem” (1919 lub 1920) autorstwa Władysława Gumplowicza (1869-1942). Podkreślano także polskie korzenie robotnika śląskiego i przywiązanie do mowy ojczystej. Szczyt kampanii plebiscytowej przypada na wiosnę 1920 roku, jednak ostatecznie do plebiscytu nie doszło i spór rozwiązano w kręgach dyplomatycznych podczas posiedzenia Rady Ambasadorów w belgijskim Spa.

W wyniku podziału, po stronie Czechosłowackiej, znalazło się około 140 tysięcy Polaków, którzy w powiecie cieszyńskim, frydeckim i frysztackim tworzyli silną grupę narodową. Czeskie tereny Śląska Cieszyńskiego zamieszkałe przez Polaków zaczęto nazywać Zaolziem, gdzie w miarę szybko Polacy zorganizowali dobrze rozwijające się struktury społeczno-kulturalne i polityczne. Międzywojenna działalność polityczna Polaków z Zaolzia w ramach państwa czechosłowackiego skupiała się na silnej reprezentacji Polaków na wszystkich szczeblach władzy państwowej, stąd ważnymi wydarzeniami były wybory do parlamentu Czechosłowacji w latach 1929 i 1935 . O ile w pierwszych wyborach Polacy reprezentowali jednolity blok wyborczy, to w latach 30. dochodzi do rozdrobnienia polskiej sceny politycznej, nic więc dziwnego, że wyborom 1935 roku towarzyszy wzmożona działalność satyryczna, najaktywniejszym staje się „Szerszeń, dodatek satyryczno-humorystyczny do „Prawa Ludu”, gazety wydawanej przez Stronnicwo Ludowe, której programem było bronienie praw narodowych i kulturowych polskojęzycznych Ślązaków. Przywódcy partii odwoływali się do polskiego solidaryzmu narodowego oraz idei tolerancji religijnej, mimo iż należeli do niej głównie polscy ewangelicy. Adresatem zjadliwych ataków „Szerszenia” (tytuł tworzył aluzję do agresywności owada) były więc wszystkie osoby i środowiska, będące politycznymi przeciwnikami partii. Szczególnie atakowano Emanuela Chobota działacza Polskiej Socjalistycznej Partii Robotniczej, zwanego przez redaktorów pobłażliwie „Manuś, za jego układanie się z czeskimi socjaldemokratami. Był też adresatem większości dowcipów i satyr o charakterze personalnym. Pismo atakowało wszelkie poczynania konkurentów politycznych, zwłaszcza tych, którzy celowo uderzali w interesy Polaków na Zaolziu, stąd ataki także na Józefa Kożdonia, przywódcę Ślązakówców, polityków czeskich i redakcje innych gazet partyjnych np. „České Slovo”, „Robotnik Śląski”. „Szerszeń” operuje 
językiem dosadnym i agresywnym, często sprowadza się do kpiny i szyderstwa. Ulubionym zabiegiem ośmieszającym jest używanie spolszczonego języka czeskiego w celu pokazania braku etnicznych Czechów w regionie zaolziańskim, a gwarę cieszyńską używa w treściach przywołujących głos prostego ludu, np. w stałej rubryce „Łod dziedziny do dziedziny” (od wioski do wioski), która jest pisana $\mathrm{w}$ formie ludowego komentarza aktualnych wydarzeń politycznych w regionie. Czasami autorzy inspirują się treściami z satyrycznego miesięcznika „Kocynder” (wydawanego w latach 1920-1939), które odegrało znaczącą rolę w okresie plebiscytu i powstań śląskich w regionie Górnego Śląska, a kilkakrotnie sięgającego po ogólnopolskie motywy satyryczne - chociażby popularną w okresie międzywojennym postać króla Afganistanu Amanullaha Chana, którego wizyta w Polsce na przełomie kwietnia i maja 1928 roku stała się wdzięcznym źródłem licznych satyr skamandryckiego „Cyrulika Warszawskiego”. W większości jednak teksty satyryczne „Szerszenia” wykorzystują kontekst i motywy regionalne, czyniąc to w sposób nieczytelny dla obiorcy, gdyż liczne komentarze mają charakter personalnych ataków redakcji na daną osobę, co utrudnia zrozumienie przekazu i kontekstu satyrycznego. Stąd wątpliwe jest, żeby polityczna satyra pisma cieszyła się popularnością wśród czytelników w odróżnieniu od licznych dowcipów towarzysko-okolicznościowych zamieszczanych na łamach „Szerszenia” dla odciążenia treści. Łącznie wyszło 32 numerów czasopisma (w latach 1934-35), a po wyborach parlamentarnych w Czechosłowacji potrzeba wydawania pisma zanika.

Satyra polityczna na Śląsku Cieszyńskim w swej retoryce często używała gwary i pojęcia śląskości jako atutu pozytywnego, obojętnie czy chodziło o satyrę czeską lub polską, przeciwstawiając jej pojęcie obcości (w znaczeniu - spoza regionu, z centrum). Sprowadzała się przede wszystkim do prostych „satyr krótkiego trwania”, osobistych wypadów i dezaprobujących ośmieszeń. Niestety w dużym stopniu nacechowana była funkcją agitacyjną, która szybko dezaktualizuje się i z reguły nie imponuje warsztatem (Mikrut 2016: 6). Trudno dziś określić, jak dużą rolę odegrała w walce politycznej tego okresu, chociaż bezspornie przyczyniła się do umocnienia niektórych istniejących stereotypów narodowych.

\section{POLITICAL SATIRE OF „CIESZYN" SILESIA IN THE INTERWAR PERIOD}

SUMMARY It's been ages since political satire was key element in rivalry of power and authority. As many literary, historical, sociological studies confirm. Comicality was always part of political communication as a ludic element of discourse. Comicality is at its most in era of crises and satire aggravates in periods of social solstice, it wasn't any different on terrains of Śląsk Cieszyński.

Present article talks about growth of political satire on turn of $20^{\text {th }}$ and $21^{\text {st }}$ century. Political satire on terrains of Śląsk Cieszyński was oftenly brought to form of simple "short satires", personal reflections and disapproving ridicules. We can hardly guess how big role was political satire playing in political wars of that particular era, however it clearly contributed on affirmation of some existing national stereotypes. Its most interesting factor is dialect-like vocabulary forming original and interesting satirical statement. 


\section{LITERATURA}

I Chlebowczyk J., 1971, Nad Olzq: Sląsk Cieszyński w wiekach XVIII, XIX i XX, Katowice.

I Dziemidok B., 1967, O komizmie, Warszawa.

I Mikrut I., 2016, Przymrużonym okiem. Radość czytania satyryków, Katowice.

I Novotný L., 2012, Metody plebiscitní kampaně na Těšinském Slezsku v letech 1919-1920, Olomouc.

I Stępień T., 1996, O satyrze, Katowice.

I Ziomek J.,1966, Komizm, parodia, trawestacja. Prace o literaturze i teatrze ofiarowane Zygmuntowi Szweykowskiemu, Wrocław.

\section{Źródła:}

I Gwiazdka Cieszyńska, nr 1, Cieszyn 1919.

I Gwiazdka Cieszyńska, nr 3, Cieszyn 1919.

I Pokrzywy, nr 6, Cieszyn 1918.

I Pokrzywy, nr 3, Cieszyn 1910.

I Pokrzywy, nr 1, Cieszyn 1909.

I Pokrzywy, nr 18, Cieszyn 1918.

I Szerszeń, nr 1-32, Czeski Cieszyn 1934-1935. 